\title{
PELATIHAN DIAGNOSIS KESULITAN BELAJAR SISWA BAGI GURU SD NEGERI GUGUS IV KECAMATAN MATARAM NTB
}

\author{
A. Hari Witono*, Heri Setiawan, M. Irawan Zain, I Ketut Widiada, M. Tahir \\ PGSD, FKIP, Universitas Mataram, Mataram NTB, Indonesia
}

\begin{abstract}
Kata Kunci:
Diagnosis

kesulitan

belajar, siswa

$S D$, guru $S D$,

gugus IV

Mataram
\end{abstract}

\begin{abstract}
Abstrak: Tujuan pengabdian masyarakat ini ialah agar guru-guru yang menjadi objek pengetahuan menguasai sejumlah pengetahuan (insight) tentang konsep teori dan keterampilan (skill) metode diagnosis kesulitan belajar. Guru SD diharapkan mampu melakukan bimbingan konseling terhadap siswa mereka. Aspek BK di SD diantaranya guru mampu mendiagnosis kesulitan belajar siswa. Faktanya di SD partisipasi guru dalam melaksanakan bimbingan konseling khususnya diagnosis kesulitan belajar masih cukup rendah. Perlu diadakan pelatihan kepada guru tentang konsep, prinsip, langkah, dan alat diagnosis kesulitan belajar siswa agar guru dapat melaksanakannya di sekolah dan dapat membantu siswa untuk menemukan solusi bagi kesulitan belajar mereka. Metode yang digunakan dalam kegiatan pengabdian kepada masyarakat ini berupa pelatihan, ceramah, tanya jawab atau diskusi dan pendampingan guru SD tentang diagnosis kesulitan belajar siswa SD. Pelaksanaanya ditempuh melalui tiga tahap. Pertama, koordinasi dengan ketua gugus dan kepada sekolah dimana kegiatan akan dilaksanakan. Kedua, kegiatan pelatihan, dan ketiga, kegiatan evaluasi dan pelaporan. Setelah dilakukan evaluasi dinyatakan bahwa kegiatan pelatihan berjalan lancar sesuai rencana, bahkan melihat peserta yang mengikuti kegiatan pelatihan cukup antusias. Banyak peserta yang menyatakan keinginan untuk dilaksanakan kegiatan lanjutan berupa pendampingan berkelanjutan diagnosis kesulitan belajar siswa di SD masing-masing.
\end{abstract}

Korspodensi email: heri_setiawan@unram.ac.id

\section{PENDAHULUAN}

Pengabdian masyarakat ini terinspirasi dari penelitian Witono, A. H dkk (2018). Ditemukan bahwa tidak lebih dari $45 \%$ guru-guru SD yang berpartisipasi aktif dalam melaksanakan bimbingan konseling sebagai tugas samping (auxalary) pelaksanaan tugas utama, pembelajaran kepada siswa di kelas (Kemendikbud, 2016). Salah bentuk partisipasi bimbingan yang dimaksukan dalam konteks ini ialah mendiagnosa siswa yang mengalami kesulitan belajar. Jika guru-guru kurang melaksanakan tugas bimbingan dan konseling dikhawatirkan muncul banyak siswa yang mengalami kesulitan belajar dan tidak mendapat pertolongan untuk keluar dari masalah-masalah belajar yang dihadapi. Tiba gilirannya banyak siswa yang memperoleh nilai rendah.

Padahal telah ditegaskan apabila Sekolah Dasar tidak/belum memiliki guru bimbingan dan konseling atau konselor maka layanan bimbingan dan konseling dilakukan oleh guru kelas sehingga materi-materi bimbingan dan konseling dapat dipadukan dengan materi ajar melalui pembelajaran tematik (Kemendikbud, 2016). Hal tersebut diperkuat dengan Permendiknas Nomor 35 Tahun 2010 tentang Petunjuk Teknis Pelaksanaan Jabatan Fungsional Guru dan Angka Kreditnya bahwa untuk guru kelas, di samping wajib melaksanakan proses pembelajaran juga wajib melaksanakan program bimbingan dan konseling terhadap peserta didik di kelas yang menjadi tanggung jawabnya. 
Dari wawancara pendahuluan yang dilakukan dengan Ibu Dra. Mar'aini, M.Pd selaku ketua Gugus IV Kecamatan Mataram pada tanggal 7-8 Januari 2019 di SD 41 diperoleh informasi banyak siswa yang nilainya di bawah target Kreteria Ketuntasan Minimal, terutama pada bidang studi Matematika dan Ilmu Pengetahuan Alam (IPA). Salah satu sebab rendahnya nilai siswa tersebut diduga bersumber dari banyaknya siswa-siswa yang mengalami kesulitan belajar. Namun siswa-siswa tersebut juga belum memperoleh bantuan layanan yang profesional dan proporsional sebagaimana yang disimpulkan dari penelitian tersebut di atas. Idealnya guru turut berperan membantu memecahkan masalah belajar yang dihadapi siswa. Peran guru melalui diagnosis dan bimbingan konseling bertujuan untuk mengetahui dimana letak kesulitan belajar yang di hadapi oleh siswa serta untuk mencari pemecahannya (Ismail, 2016:31).

Berdasar penelitian yang dilakukan Witono, dkk (2018), juga diperoleh informasi bahwa guru di Gugus IV Kecamatan Mataram masih jarang memperoleh pelatihan (inservice training), workshop, dan diklat tentang bimbingan konseling yang melibatkan guru (baik yang dilaksanakan oleh Diknas dan LPMP sebagai pihak bertanggung jawab meningkatkan mutu kerja guru). Hal ini mengisyaratkan bahwa persoalan kompetensi guru, di bidang bimbingan konseling belum memperoleh perhatian dari pihak-pihak terkait.

Dampak kurangnya pelatihan (inservice training) yang diperoleh guru tidak hanya berakibat pada kualitas kinerja guru menjadi rendah (Witono dkk, 2018), tetapi juga berimbas kepada siswa. Semakin banyak siswa yang belum memperoleh layanan pendidikan yang lebih berorientasi pada aspek non kognitif. Muara akhir yang menjadi kekhawatiran yaitu rendahnya hasil belajar yang dicapai oleh siswa utamanya di SDN gugus IV kota Mataram.

Sebagai alternatif pemecahan masalah yang dihadapi guru-guru SD Negeri Gugus IV Kecamatan Mataram sebagai sasaran kegiatan pengabdian ini, yang berakhir pada rendahnya prestasi belajar siswa sebagaimana diuraikan sebelumnya, maka perlu dilakukan sebuah kegiatan yang menjadi pengabdian masyarakat bagi Lembaga Universitas Mataram. Bentuk pengabdian yang dapat menjadi alternatif dalam meningkatkan kompetensi guru bidang bimbingan, berupa pelatihan bagi guru agar mampu melakukan Diagnosa Kesulitan Belajar bagi guru-guru SD. Guru-guru perlu dibekali dengan pengetahuan, konsep, serta teknik diagnosis kesulitan belajar, sehingga mampu membimbing \& melakukan konselin di sekolah masing-masing.

Diharapkan dari kegiatan pengabdian ini memiliki multieffect. Manfaat bagi guru yaitu memperoleh pengetahuan (insight), terutama dalam keterampilan ( $k$ kill) mendiagnosa siswa yang mengalami kesulitan belajar. Bagi siswa yang mengalami kesulitan belajar, juga akan memperoleh manfaat tidak langsung (undirectly benefit) yaitu masalah yang dihadapi segera memperoleh bantuan pemecahannya. Dengan kata lain guru-guru yang telah terampil mendiagnosa kesulitan belajar diharapkan akan menerapkan ilmunya kepada siswa, memberi pelayanan profesional bimbingan berupa diagnosis kesulitan belajar siswa di kelas sehingga gejala siswa yang mengalami kesulitan belajar akan makin berkurang. 


\section{METODE KEGIATAN}

Untuk mencapai tujuan pelatihan seperti yang tersirat dalam judul pengabdian masyarakat ini digunakan beberapa metode, yaitu ceramah, tanya jawab atau diskusi dan pendampingan.

1. Metode ceramah dan presentasi digunakan saat menyajikan materi kepada guru-guru SD Gugus IV Kecamatan Mataram tentang: i) pengertian kesulitan belajar siswa dan diagnosis kesulitan belajar siswa, ii) kriteria siswa yang mengalami kesulitan belajar, iii) Pentingnya diagnosis kesulitan belajar siswa bagi pembelajaran dan bagi siswa penerima jasa langsung proses pembelajaran yang dilaksanakan guru, dan iv) tahapan dan teknik diagnosis kesulitan belajar siswa SD; tahapan menyusun persiapan, menyusun perangkat yang diperlukan, pelaksanaan diagnosis dan evaluasi keberhasilan diagnosis kesulitan belajar siswa.

2. Metode tanya jawab, dimaksudkan untuk memberi kesempatan kepada khalayak sasaran pengabdian masyarakat ini, tentang materi-materi yang mungkin belum dipahami dalam metode poin a, serta masalah-masalah lain yang berhubungan dengan diagnosis kesulitan belajar siswa.

3. Metode pendampingan, digunakan Tim pengabdian sejak dari persiapan, pelaksanaan dan akhir pelaksanaan pengabdian, berupa evaluasi proses dan produk pengabdian.

Pelaksanaanya ditempuh melalui tiga tahap. Pertama, koordinasi dengan ketua gugus dan kepada sekolah dimana kegiatan akan dilaksanakan. Kedua, kegiatan pelatihan, dan ketiga, kegiatan evaluasi dan pelaporan.

1. Koordinasi dilakukan secara intens agar terjadi kesepakatan dan kesepahaman dengan kepala SD Negeri gugus IV kota Mataram. Koordinasi dilaksanakan sebagai bentuk perizinan, perencanaan, dan pematangan konsep kegiatan. Dalam tahap ini pula ditentukan banyak peserta, bentuk kegiatan, waktu, dan tempat pelaksanaan. Koordinasi dilaksanakan pada akhir bulan Juli - awal bulan Agustus 2019.

2. Tahap inti yaitu kegiatan pelatihan dimana tim pengabdian menyampaikan presentasi dengan metode cermah dan presentasi, tanya jawab, dan pendampingan kepada peserta. Materi yang disampaikan berkaitan dengan diagnosis kesulitan belajar siswa dan pendampingan kepada guru dalam latihan diagnosis siswanya yang diduga mengalami kesulitan belajar. Kegiatan dilaksanakan di pusat gugus IV Kota Mataram yaitu SD Negeri 40 Mataram, pada hari sabtu tanggal 24 Agustus 2019.

3. Tahap kegiatan evaluasi dan pelaporan. Tim pengabdian melakukan evaluasi dan pelaporan guna melihat capaian kegiatan serta pertanggugjawaban atas kegiatan pelatihan yang telah dilaksanakan. Luaran kegiatan ini berupa laporan pengabdian dan artikel pengabdian.

\section{HASIL DAN PEMBAHASAN}

Kegiatan pengabdian masyarakat ini berbentuk pelatihan, yang dapat dikelompokan ke dalam dua bentuk kegiatan, yaitu ceramah umum dan tanya jawab, serta pemberian latihan terbimbing. Pelaksanaannya dilakukan di SDN 40 Mataram sebagai pusat gugus IV Mataram pada hari sabtu 24 Agustus 2019. Peserta yag hadir terdiri atas 6 kepala sekolah dan 30 guru 
dari masing-masing SD anggota gugu IV. Adapun jabaran pelaksanaan penyampaian materi pelatihan dan kegiatan pendampingan sebagai berikut.

Materi pertama adalah pengenalan konsep dan pengertian tentang kesulitan belajar dan diagnosis kesulitan belajar. Konsep dan pengertian disampaikan diawal agar terjadi kesepahaman antara pemateri dan peserta. Materi yang disampaikan berupa; (1) pengertan belajar; (2) faktor yang mempengaruhi belajar; (3) definisi kesulitan belajar; (4) macam dan jenis kesulitan belajar; dan (5) definisi diagnosis kesulita belajar.
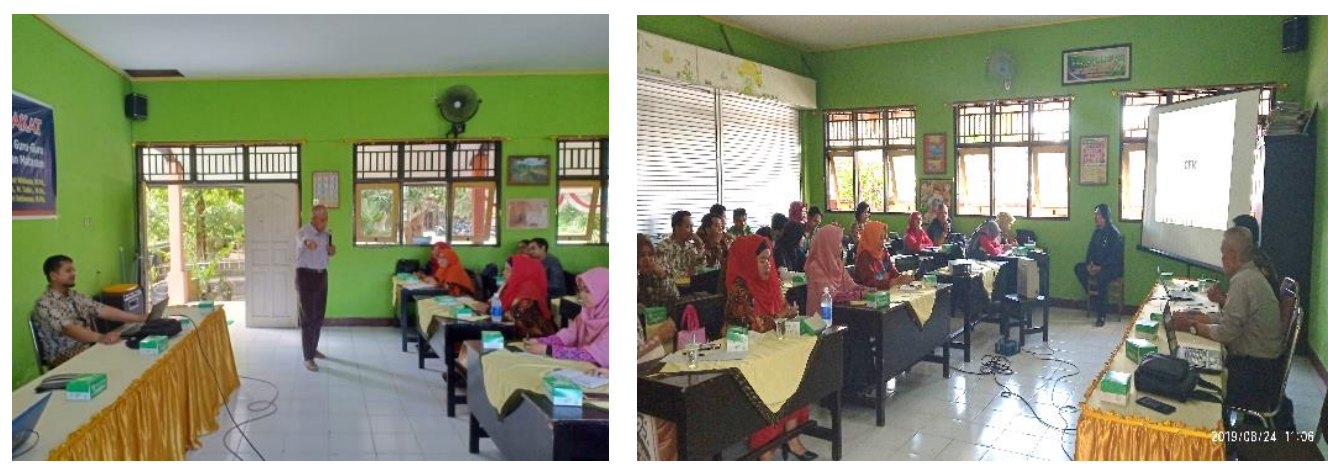

Gambar 1 \& 2. Penyampaian materi tentang diagnostik kesulitan belajar siswa di SD

Materi yang kedua disampaikan yaitu tentang kriteria siswa yang diduga mengalami kesulitan belajar. Esensi dari materi tersebut mengacu pada kriteria yang disampaikan oleh Warkitri, dkk (1998:8.5-8.6) dimana kesulitan atau masalah belajar dapat dikenal berdasarkan gejala yang dimanifestasikan dalam berbagai bentuk perilaku, baik secara kognitif, afektif, maupun psikomotorik. Siswa yang diduga mengalami kesulitan belajar menunjukkan gejala sebagai berikut; (1) hasil belajar yang dicapai rendah dibawah rata-rata kelompoknya; (2) hasil belajar yang dicapai sekarang lebih rendah dibanding sebelumnya; (3) hasil belajar yang dicapai tidak seimbang dengan usaha yang telah dilakukan; (4) lambat dalam melakukan tugas-tugas belajar; (5) menunjukkan sikap yang kurang wajar, misalnya masa bodoh dengan proses belajar dan pembelajaran, mendapat nilai kurang tidak menyesal, dst; (6) menunjukkan perilaku yang menyimpang dari norma, misalnya membolos, pulang sebelum waktunya, dst; (7) menunjukkan gejala emosional yang kurang wajar, misalnya mudah tersinggung, suka menyendiri, bertindak agresif, dst.

Materi ketiga disampaikan tentang pentingnya diagnosis kesulitan belajar siswa bagi pembelajaran dan bagi siswa penerima bimbingan. Materi ini merujuk pada hasil penelitian Witono, dkk (2018) bahwa di SD guru masih jarang melaksanakan bimbingan konseling khususnya diagnosis kesulitan belajar yang dialami siswa. Manfaat pelaksanaan diagnostik kesulitan belajar yaitu guru dapat menentukan pembelajaran yang tepat mulai dari perencanaan, penyiapan materi, metode, media, serta evaluasi sesuai dengan keadaan kelas. Karena tentu berbeda perlakuan pembelajaran untuk kelas dengan siswa berkesulitan belajar dengan kelas yang biasa.

Pertimbangan utama urgensi pelaksanaan diagnostik kesulitan belajar siswa (Ismail, 2016:40) yaitu: (1) siswa hendaknya mendapat kesempatan dan pelayanan untuk berkembang secara maksimal; (2) adanya perbedaan kemampuan, kecerdasan, bakat, minat, dan latar belakang lingkungan masing-masing siswa; (3) sistem pengajaran di sekolah seharusnya 
memberi kesempatan pada siswa untuk maju sesuai dengan kemampuannya; dan (4) untuk menghadapi permasalahan yang dihadapi oleh siswa, hendaknya guru lebih intensif dalam menangani siswa dengan menambah pengetahuan, sikap yang terbuka dan mengasah keterampilan dalam mengindentifikasi kesulitan belajar siswa.

Adapun materi keempat tentang teknik dan tahapan diagnosis kesulitan belajar. Diagnosis kesulitan belajar dilakukan dengan teknik tes dan nontes. Teknik tes dilakukan dengan dua jenis tes yaitu tes prasyarat (prasyarat pengetahuan, prasyarat keterampilan) dan tes diagnostik. Sedangkan diagnosis melalui teknik nontes dapat ditempuh melalui wawancara dan pengamatan (Ismail, 2016:40).

Untuk melaksanakan kegiatan diagnosis kesulitan belajar harus ditempuh beberapa tahapan kegiatan. Tahapan tersebut meliputi (Warkitri, dkk. 1998:8) beberapa tahap berikut (1) mengidentifikasi siswa yang diperkirakan mengalami kesulitan belajar; (2) melokalisasikan kesulitan belajar; (3) menentukan faktor penyebab kesulitan belajar; (4) memperkirakan alternatif bantuan; (5) menetapkan kemungkinan cara mengatasinya; dan (6) Tindak lanjut. Selain 6 tahapan tersebut materi dilengkapi dengan alur atau tahapan menyusun persiapan, menyusun perangkat yang diperlukan, pelaksanaan diagnosis dan evaluasi keberhasilan diagnosis kesulitan belajar siswa.

Kegiatan tanya jawab dilaksanakan sepanjang jeda pemaparan materi. Peserta yang mengalami kesulitan memahami atau mengerti materi diberi kesempatan untuk bertanya. Tim pengabdian memberikan jawaban dengan jelas agar peserta tidak mengalami kebingungan. Semua peserta diberikan kesempatan yang sama untuk bertanya dan menyampaikan pendapat.
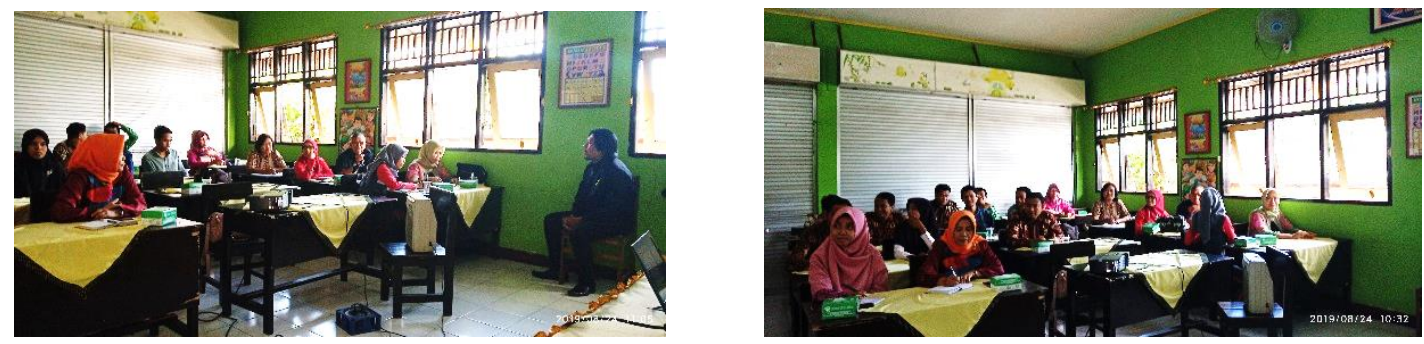

Gambar 3 \& 4. Pelaksanaan tanya jawab dengan peserta dan pendampingan latihan diagnostik kesulitan belajar siswa di kelas yang diampu.

Sesi kedua dilaksanakan dengan pendampingan peserta untuk berlatih melakukan diagnostik bagi siswa yang mereka ajar. Tim pengabdian memberikan form latihan diagnostik agar peserta tidak kebingungan. Siswa yang didagnosis dipilih berdasarkan ciri-ciri yang telah dipaparkan pada materi kedua. Latihan ini dilaksanakan dengan mengelompokkan guru sesuai dengan tingkatan kelas meskipun berbeda asal SD.

Pendampingan latihan dilaksanakan selama 2 jp dengan tujuan peserta betu-betul memahami dan mampu mengaplikasikan konsep diagnostik kesulitan belajar siswa di kelas yang diampu. Melalui kegiatan diskusi kelompok sesuai dengan tingkat kelas yang diampu, diaharapkan guru bisa saling memberikan masukan dan solusi apabila ditemukan siswa dengan dugaan kesulitan belajar dikelas tersebut. Sehingga guru pada akhirnya dapat menentukan tindakan yang perlu diambil, langkah apa yang perlu ditempuh, dan mampu 
menyesuaikan dengan penentuan pembelajaran yang akan dilaksanakan. Penyesuaian bisa dalam bentuk pemberian treatment khusus (indikator, tujuan pembelajaran khsusu, media, metode, bahkan evaluasi khusus) bagi siswa dengan dugaan kesulitan belajar.

Selain guru, kepala sekolah juga dikelompokkan menjadi satu kelompok tersendiri. Tujuannya adalah agar kepala sekolah juga memahami apa peranan yang dapat dilakukan apabila ada siswa yang mengalami kesulitan belajar. Program ataupun bentuk dukungan apa yang dapat beliau lakukan sehingga semua siswa dapat memperoleh hak belajar sesuai dengan potensinya. Khusus untuk kepala sekolah, tugas yang diberikan adala identifikasi dukungan, kebijakan, dan peran apa yang dapat dilakukan guna mendukung pelaksanaan diagnosis kesulitan belajar bagi siswa SD.

\section{Faktor Penghambat dan Faktor Pendorong}

1. Faktor Penghambat

Faktor penghambat kegiatan pengabdian pada masyarakat ini dapat dikatakan tidak ada hambatan yang berarti, atau kegiatan ini dapat terlaksana sesuai dengan rencana, dan sesuai dengan jadwal yang telah disusun. Selama pelaksanaan kegiatan pelatihan, seluruh peserta menunjukkan komitmen yang tinggi. Ini dibuktikan dengan kehadiran mereka dalam seluruh sesi kegiatan mencapai 95\%. Peserta semua bersemangat dan antusias dalam mengikuti rangkaian pelatihan.

Dari awal kegiatan hingga kegiatan berakhir peserta mengikuti dengan saksama untuk menguasai dan mengimplementasikan semua materi yang berhubungan dengan diagnosis kesulitan belajar siswa SD. Hal ini dipertegas dengan pernyataan yang diperoleh melalui hasil wawancara bebas dan tanggapan seusai sesi I dan sesi II berakhir. Peserta menyatakan bahwa kegiatan menambah wawasan mereka. Harapan peserta kegiatan inservice training seperti ini dilaksanakan lagi pada guru-guru SD Gugus IV Kecamatan Mataram di masa-masa yang akan datang. Sebagian besar dari mereka ingin segera mencoba melakukan diagnosis kesulitan belajar siswa pada kelas yang diajar di tempat tugas mereka masing-masing,

2. Faktor Pendorong

Faktor pendorong utama kegiatan pengabdian pada masyarakat ini adalah:

a. Sikap positif dan kooperatif seluruh Kepala sekolah beserta Guru SD Se-gugus IV Kecamatan Mataram. Dukungan moral dan material dalam pelaksanaan kegiatan terutama dalam menyediakan tempat dengan segala perlengkapannya. Hal ini dapat dipahami semata-mata karena ada dorongan yang kuat dari mereka sebagai upaya peningkatan kompetensi, kapabilitas, serta keterampilan guru. Keinginan untuk terus mengaktualisasi pengetahuan dan kompetensi, utamanya dalam bidang pendukung yaitu melakasanakan bimbingan konseling di SD. serta terciptanya peningkatan kinerja guru sehingga dapat memberikan pelayanan pembelajaran berkualitas sesuai dengan kebutuhan dan karakteristik siswa yang ada di kelas yang diampu.

b. Pengabdian pada masyarakat ini dapat berjalan dengan lancar sudah tentu didukung oleh berbagai pihak baik dukungan berupa perizinan maupun dukungan moral/material. 


\section{KESIMPULAN DAN SARAN}

Berdasarkan uraian pada pembahasan diatas dapat disimpulkan sebagai berikut.

1. Kegiatan pengabdian kepada masyarakat ini telah berjalan dengan lancar. Kegiatan ini berbentuk penyuluhan yang berlangsung pada bulan Agustus 2019, bertempat di SDN 40 Mataram sebagai pusat gugus. Guru yang terlibat dalam kegiatan pelatihan ini berjumlah 30 orang dari berbagai SD di gugus IV Kecamatan Kota Mataram.

2. Pelaksanaan kegiatan pengabdian ini cukup berhasil. Hal ini mengacu pada antusiasme dan tanggapan positif dari peserta yang menyatakan bahwa dari kegiatan pelatihan ini mereka memperoleh wawasan pengetahuan tentang konsep kesulitan belajar yang dialami siswa, tugas konseling yang dilakukan oleh guru SD, serta diagnosis belajar yang dialami siswa di sekolah. Peserta termotivasi untuk melaksanakan diagnosis kesulitan belajar yang dialami siswa di kelas yang diajar.

3. Kegiatan pengabdian ini, dilaksanakan terutama berkaitan dengan tugas guru yaitu melaksanakan bimbingan kepada siswa sebagai langkah awal memahami teknik, metode, serta aplikasi diagnosis kesulitan siswa dalam belajar di sekolah perlu dilakukan pelatihan dan pendampingan secara merata dan berkesinambungan bagi semua guru SD utamanya di lingkup Kota Mataram.

4. Dukungan dari berbagai pihak untuk pelaksanaan dan pendampingan secara berkelanjutan bagi guru dilapangan dalam melaksanakan diagnosis kesulitan belajar bagi siswa di kelas yang diampu.

5. Adanya kontinyuitas dan sinergi dari berbagai pihak utamanya dinas/isntansi terkait adanya pelatihan lebih mendalam tentang tugas konseling dan diagnosis kesulitan belajar siswa di tingkat sekolah dasar.

6. Pengadaan instrumen diagnosis dan buku pedoman yang bersifat praktis bagi guru di SD untuk melaksanakan bimbingan konseling dan diagnosis kesulitan belajar bagi siswa mereka.

\section{UCAPAN TERIMA KASIH}

Tim pengabdian kepada masyarakat mengucapkan terima kasih kepada Universitas Mataran yang telah mendanai kegiatan pelatihan diagnosis kesulitan belajar siswa bagi guru SD gugus IV Kecamatan Mataram melalui dana PNBP tahun 2019 dan tim pengabdian yang telah meluangkan waktu dan tenaga hingga selesai laporan dan artikel ini. Ucapan terima kasih juga disampaikan kepada peserta yaitu guru-guru serta kepala SDN gugu IV seKecamatan Mataram yang terlibat aktif dan atas kerjasama yang baik dengan tim pengabdian.

\section{DAFTAR PUSTAKA}

Ismail. 2016. Diagnosis Kesulitan Belajar Siswa dalam Pembelajaran Aktif di Sekolah. Jurnal Edukasi. (2) 1, p 30-43.

Kemendikbud. 2016. Panduan Operasional Penyelenggaraan Bimbingan Dan Konseling Sekolah Dasar (SD). Jakarta: Dirjen GTK Kemendikbud.

PERMENDIKNAS No. 35 Tahun 2010 tentang Petunjuk Teknis Pelaksanaan Jabatan

Fungsional Guru dan Angka Kreditrnya. Jakarta: Kementerian Pendidikan Nasional. 
Warkitri, dkk. 1998. Penilaian Pencapaian Hasil Belajar. Jakarta: Universitas Terbuka press.

Witono, A. Hari. 2018. Partisipasi Guru dalam Pelaksanaan Bimbingan dan Konseling (BK) di SD Kota Mataram NTB. Penelitian dibiayai dengan Dana DIPA (PNBP) Unram 2018. LPPM Universitas Mataram. 